Jurnal Pengabdian kepada Masyarakat

\title{
Pemberdayaan Kelompok Sadar Wisata (Pokdarwis) "Tiram Tambun" dalam Pengembangan Usaha Homestay Di Desa Wisata Mentawir Kabupaten Panajam Paser Utara
}

\author{
Yogiana Mulyani ${ }^{1}$, Ranti Rustika ${ }^{2}$, Henry Winnarko $^{3}$, dan Tri Retno Nugroho ${ }^{4}$ \\ 1,2,3,4 Politeknik Negeri Balikpapan, \\ *yogiana.mulyani@poltekba.ac.id
}

\begin{abstract}
Kata Kunci: Abstrak. Pengelolaan Desa Wisata Mentawir Kabupaten panajam Paser Utara Desa Wisata, dilakukan oleh kelompok masyarakat yang tergabung dalam Kelompok Sadar Wisata Kelompok Sadar Wisata (Pokdarwis), Homestay (Pokdarwis) Tiram Tambun. Dalam pengembangan Desa Wisata Mentawir salah satu persyaratan yang harus dipenuhi adalah tersedianya sarana akomodasi atau penginapan yang memadai dalam bentuk homestay. Pokdarwis Tiram Tambun sudah mulai mengembangkan beberapa rumah tempat tinggalnya untuk bisa dijadikan homestay. Namun demikian kurangnya pengetahuan dan ketrampilan yang dimiliki tentang homestay menyebabkan tidak maksimalnya pengelolaan yang dilakukan. Oleh karenanya dalam kegiatan pengabdian masyarakat ini diberikan pelatihan dan pendampingan kepada Pokdawis Tiram Tambun tentang pengelolaan homestay Hasil kegiatan ini berupa peningkatan wawasan serta bertambahnya pengetahuan dan ketrampilan tentang pengelolaan homestay. Hal ditunjukan dengan penambahan jumlah homestay serta adanya usaha untuk memenuhi beberapa standar kriteria homestay
\end{abstract}

Keywords: $\quad$ Abstract. The management of Mentawir Tourism Village in Panajam Paser Utara Village

Toursm, Tiram Tambun

Tourism

Awareness

Grou, Homestay Regency is carried out by community who are the members of the Tiram Tambun Tourism Awareness Group. In developing Mentawir Tourism Village, one of the requirements that must be fulfilled is the availability of accommodation or lodging facilities in the form of a homestay. Tiram Tambun has started to develop several houses to be used as homestays. However, the lack of knowledge and skills about the homestay causes the management to be not optimal. Therefore, in this community service activity, training and assistance were given to Tiram Tambun regarding homestay management. The results of this activity are in the form of increased insight and knowledge also skills about homestay management. This is indicated by the addition of the number of homestays and the existence of efforts to meet several standard homestay criteria. 


\section{PENDAHULUAN}

Kawasan Mentawir memiliki potensi kepariwisataan yang dapat dikembangkan untuk menjadi berbagai daya tarik wisata. Daya tarik wisata alam yang ada di Kawasan Mentawir antara lain kawasan hutan mangrove, jeram, hutan bambu, pesona panorama gunung dan hutan tropis, wisata budaya seperti tarian ronggeng serta wisata buatan yakni rumah lodaya.

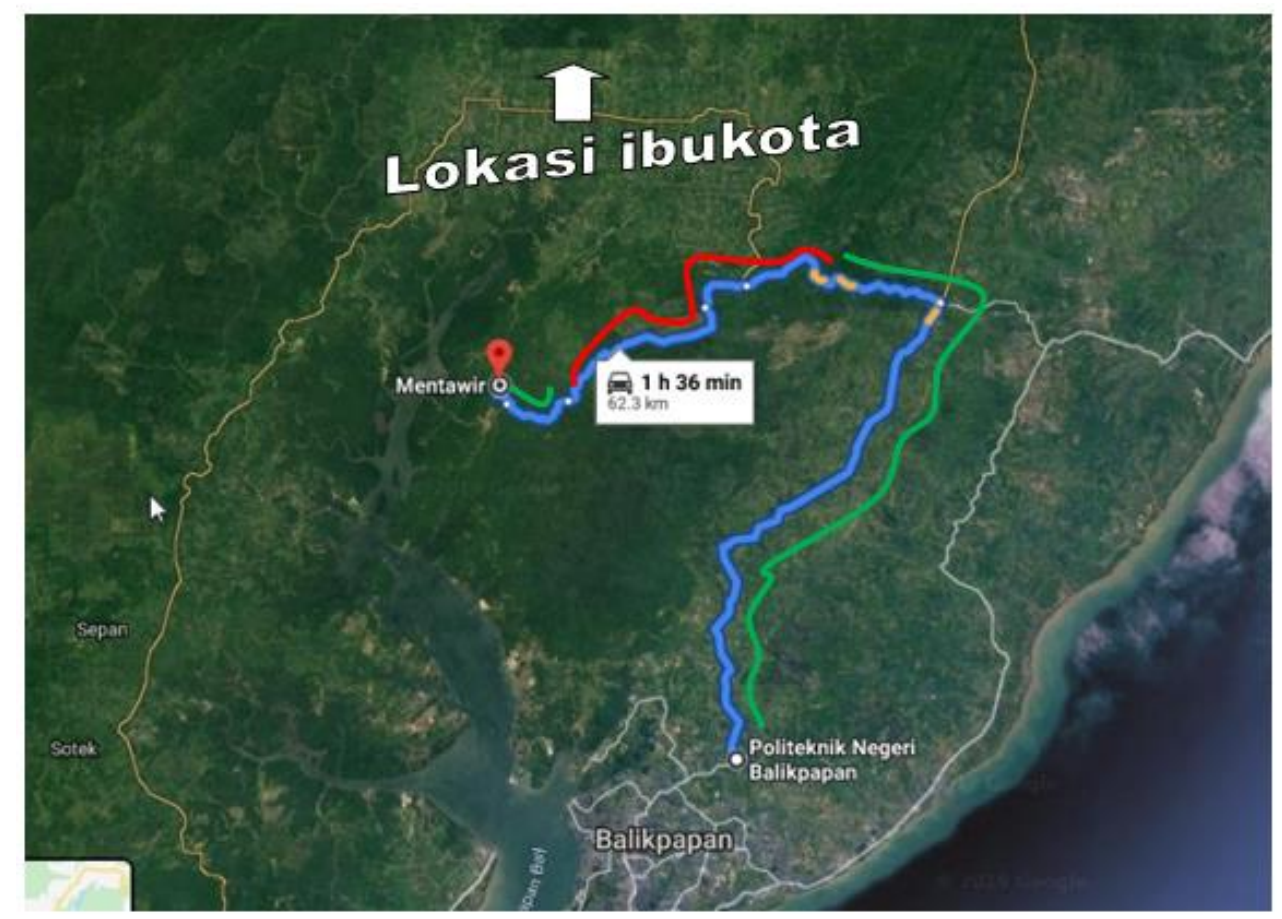

Ket: Rute perjalanan dari PT ke mitra ( - : Jalan aspal bagus; - : Jalan rusak)

\section{Gambar 1 Rute Menuju Mitra}

Luas Kelurahan Mentawir adalah 132,24 km² dimana mayoritas mata pencaharian terbesar dari penduduknya adalah nelayan, petani dan pekerja swasta di perusahaan tambang. 


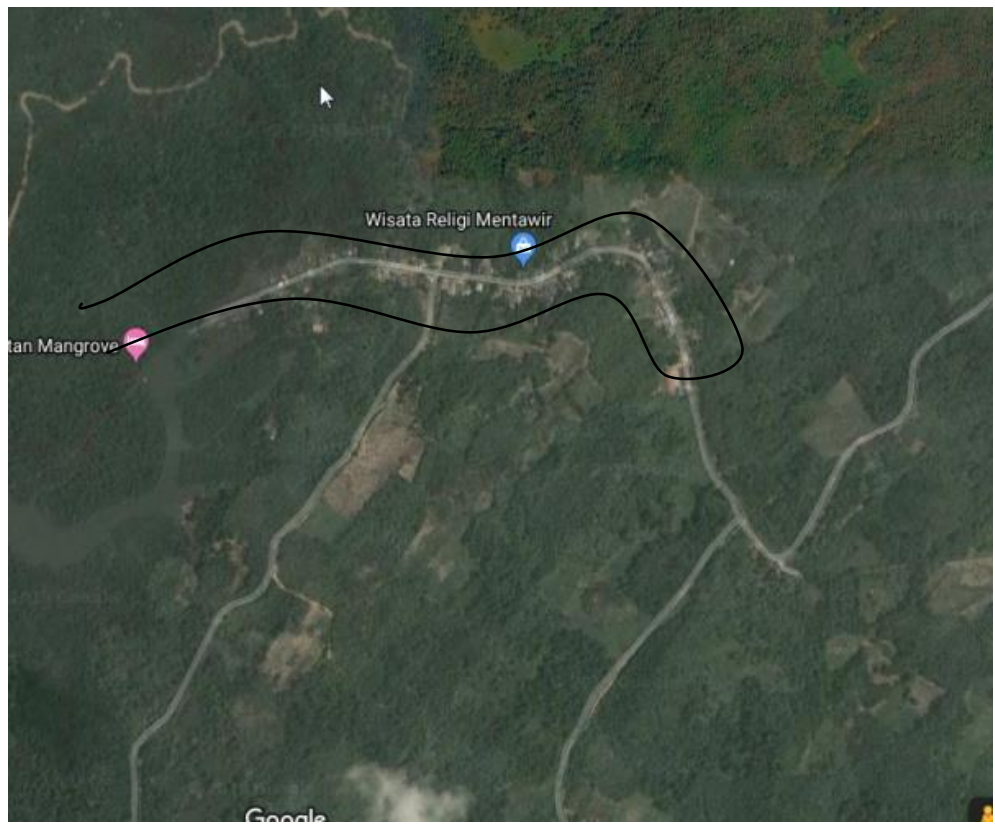

Gambar 2 Gambaran Penyebaran Penduduk Mitra

Dari 372 penduduk dewasa, mayoritas tingkat pendidikannya adalah lulusan SD hingga saat ini, hanya 2 orang yang tercatat sedang menempuh pendidikan sarjana, selebihnya langsung bekerja selepas SMA. Baik sebagai nelayan/ petani, maupun di lokasi tambang. Berikut grafik tingkat pendidikan penduduk dewasa Kel. Mentawir.

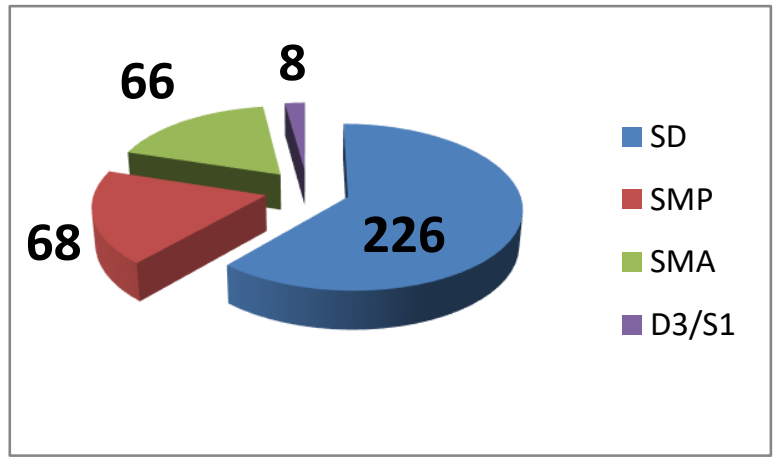

Sumber: Diolah dari Data Perkembangan Penduduk Kelurahan, Mei 2019

Dari 4 RT yang ada di Mentawir, RT 01 terletak paling ujung yang merupakan daerah pesisir/ tepi teluk Balikpapan, ditandai adanya dermaga dan kawasan hutan mangrove, sekaligus pintu masuk Kelurahan Mentawir dari jalur laut dan teluk Balikpapan. Selain itu perlunya penelusuran mengenai komponen produk pariwisata itu bisa terdiri dari angkutan wisata, atraksi wisata, dan akomodasi pariwisata di desa wisata. Produk wisata pada kawasan hutan mangrove yang berada di aliran sungai Tiram Tambun inilah yang menjadi daya tarik wisata utama di sana yang sering dikunjungi oleh para wisatawan yang berasal dari lain. Dari mulai wisata memancing, rombongan siswa sekolah, hingga wisata regular masyarakat. 
Untuk wisatawan asing biasanya yang berkunjung adalah wisatawan minat khusus, yakni para peneliti.

Berbagai daya tarik wisata yang ada (Gambar 3) tersebut menjadikan Kawasan Mentawir lebih jauh memungkinkan untuk bisa dikembangkan menjadi salah satu Desa Wisata yang ada di Kabupaten Panajam Paser Utara. Desa Wisata merupakan suatu daerah tujuan wisata atau disebut pula destinasi pariwisata yang mengintegrasikan daya tarik wisata, fasilitas umum, fasilitas pariwisata, aksesibilitas yang disajikan dalam suatu struktur kehidupan masyarakat yang menyatu dengan tata cara dan tradisi yang berlaku (Tim Master Trainer Desa Wisata 2019). Sedangkan menurut Muljadi (2012) Desa Wisata merupakan pengembangan suatu wilayah desa yang pada dasarnya tidak merubah apa yang sudah ada akan tetapi lebih cenderung kepada pengembangan potensi desa yang ada dengan melakukan pemanfaatan kemampuan unsur-unsur yang ada di dalam desa yang berfungsi sebagai atribut produk wisata dalam skala yang kecil menjadi rangkaian aktivitas atau kegiatan pariwisata dalam mampu menyediakan serta memenuhi serangkaian kebutuhan perjalanan wisata baik dari aspek daya tarik maupun sebagai fasilitas pendukung.
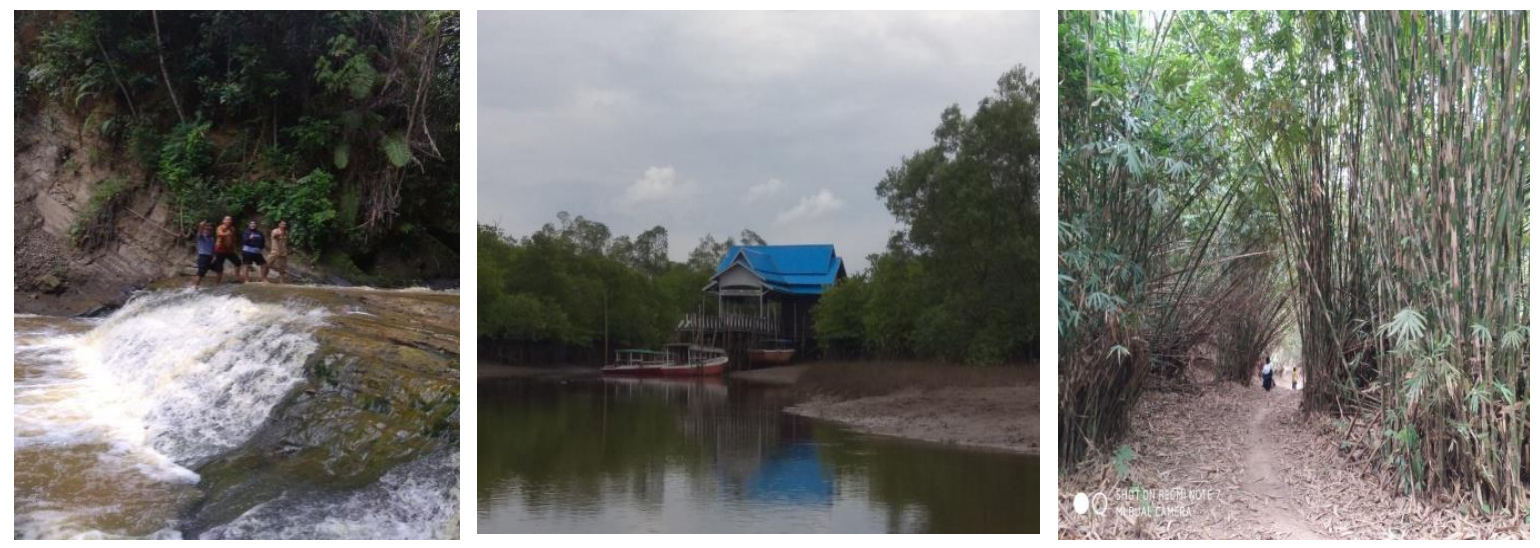

\section{Gambar 3 Daya Tarik Wisata Alam Di Desa Wisata Mentawir Sumber : Tim Pelaksana PkM Poltekba}

Saat ini pengelolaan Desa Wisata Mentawir yang masih masuk dalam kategori Desa Wista Rintisan dilakukan oleh Kelompok Sadar Wisata (Pokdarwis) Tiram Tambun. Pokdarwis adalah kelembagaan di tingkat masyarakat yang anggotanya terdiri dari para pelaku kepariwisataan yang memiliki kepedulian dan tanggungjawan serta berperan sebagai penggerak dalam mendukung terciptanya iklim kondunsif bagi tumbuh berkembangnya kepariwisataan serta terwujudnya Sapta Pesona dalam meningkatkan pembangunan daerah melalui kepariwisataan dan manfaatkan bagi kesejahteraan masyarakat sekitar (Rahim, 2012). Pokdarwis Tiram Tambun dibentuk pada tahun 2019 yang saat ini memiliki 38 (tiga puluh delapan) orang anggotanya. Dalam pengembangan Desa Wisata Mentawir untuk bisa ke kategori yang lebih tinggi lagi maka harus memenuhi beberapa persyaratan yang telah ditetapkan. Salah satu persyaratan tersebut adalah adanya sarana akomodasi atau penginapan yang memadai dalam bentuk homestay. Homestay adalah sarana fasilitas pendukung penting dalam pengembangan Desa Wisata untuk memenuhi akomodasi wisatawan. 
Homestay is where guests will stay with the host's family and experience the everyday way of life of the family and community in both a direct and indirect manner (ASEAN Homestay Standard.2011). Ini dapat diartikan bahwa homestay adalah salah satu bentuk akomodasi yang menggunakan rumah tinggal, menyediakan kesempatan bagi tamu/wisatawan untuk menjalani kehidupan sehari-hari bersama keluarga pemilik rumah atau komunitas baik secara langsung atau tidak langsung. Sehingga bisa dikatakan homestay bukan hanya sekedar sarana akomodasi tetapi juga bisa sekaligus menjadi daya tarik wisata juga .Sebagai usaha dalam desa wisata, homestay diharapkan dapat memberikan dampak positif bagi peningkatan taraf kehidupan masyarakat di Desa Wisata. Homestay juga dapat didifinisikan sebagai rumah tinggal masyarakat, yang sebagian kamarnya disewakan kepada tamu dalam jangka waktu tertentu. Tamu yang menginap pada homestay dapat mempelajari budaya setempat atau suatu rutinitas tertentu (Krisnawati dan Krisanto, 2018)
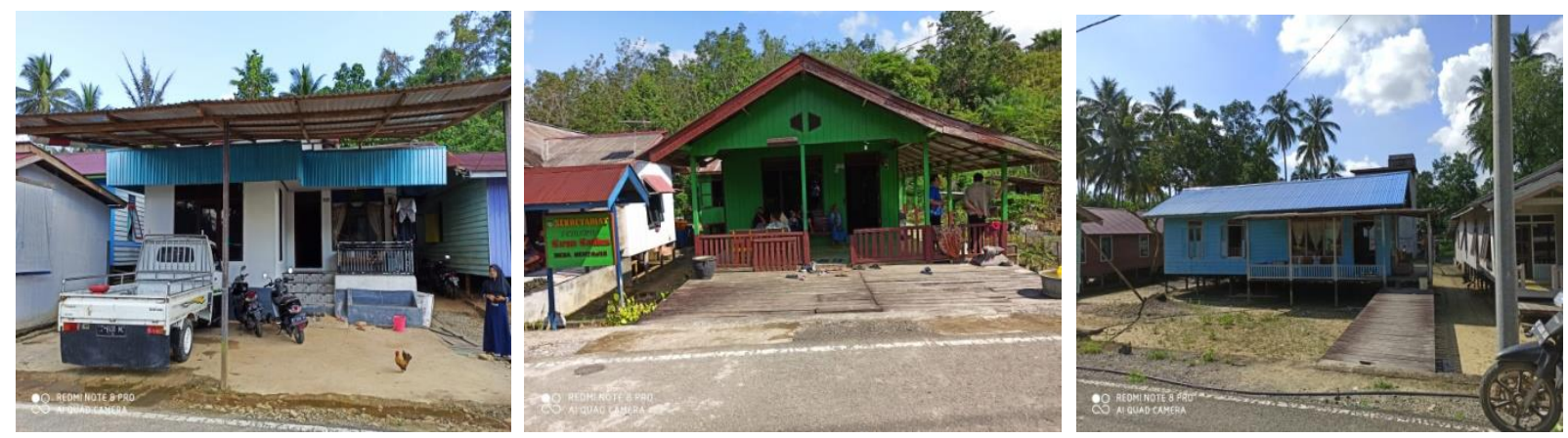

Gambar 4. Beberapa Homestay yang akan Dikembangkan Di Desa Wisata Mentawir Sumber : Tim Pelaksana PkM Poltekba

Dalam Permenparekraf No.18 Tahun 2018 pengertian Homestay selaras dengan pengertian Pondok Wisata yakni jenis akomodasi rumah tinggal yang dihuni oleh pemiliknya dan dimanfaatkan untuk disewakan dengan memberikan kesempatan kepada wisatawan untuk berinteraksi dalam kehidupan sehari-hari pemiliknya, yang dimiliki oleh masyarakat setempat dalam rangka pemberdayaan ekonomi lokal. Sehingga untuk standar kriteria homestay dipakai sama dengan standar kriteria untuk Pondok Wisata.

Pokdarwis Tiram Tambun saat ini sudah mulai mengembangkan beberapa usaha homestay dengan memanfaatkan rumah tempat tinggal mereka untuk disewakan kepada para wisatawan yang datang berkunjung ke Desa Wisata Mentawir. Namun demikian dari survey yang dilakukan homestay (Gambar 4) yang ada di Desa Wisata Mentawir masih belum dikelola secara maksimal dan belum memenuhi standard kriteria yang dipersyaratkan baik dari aspek produk, pelayanan dan penegelolaannya. Permasalahan yang dihadapi oleh Pokdarwis Tiram Tambun dalam mengembangkan usaha homestay dapat di idenfikasi sebagai berikut.

a. Kurangnya pemahaman Pokdarwis Tiram Tambun mengenai homestay di desa wisata

b. Tidak adanya pengetahuan Pokdarwis Tiram Tambun tentang standard kriteria homestay

c. Kurangnya ketrampilan Pokdarwis Tiram Tambun dalam penataan kamar homestay. 
Oleh karenanya untuk membantu mengatasi permasalahan yang dihadapi sebagaimana yang telah disebutkan maka perlu dilakukan peningkatan sumber daya manusia baik untuk wawasan, pengetahuan dan ketrampilan dari Pokdarwis Tiram Tambun dalam hal pengelolaan homestay sehingga bisa lebih berdaya dalam mengembangkan usaha homestay yang ada di Desa Wisata Mentawir.

Mentawir, salah satu desa yang berada di Penajam, Kalimantan Timur, mulai mengembangkan sektor pariwisata dengan menggali potensi-potensi wisata yang ada didaerah tersebut. Salah satu yang sedang dikembangkan oleh desa Mentawir adalah Desa Wisata. Menurut Priasukmana \& Mulyadin (2013), Desa Wisata adalah suatu kawasan pedesaan yang menawarkan keseluruhan dari suasana yang mencerminkan keaslian dari pedesaaan itu sendiri mulai dari sosial budaya, adat istiadat, keseharian, memiliki arsitektur bangunan dan struktur tata ruang desa yang khas dan dari kehidupan sosial ekonomi atau kegiatan perekonomian yang unik dan menarik serta mempunyai potensi untuk dikembangkanya berbagai komponen kepariwisataan, misalnya atraksi, akomodasi, makanan-minuman, cinderamata, dan kebutuhan wisata lainnya. Desa Mentawir mengubah desanya menjadi desa wisata diawali dengan menjadi desa wisata rintisan. Desa wisata mentawir melibatkan seluruh masyarakat desa untuk terlibat dalam kegiatan pariwisata desa tersebut. Desa Wisata Mentawir mengambil konsep pariwisata berbasis masyarakat (Community Based Tourism).

Pembangunan pariwisata berbasis masyarakat merupakan salah satu konsep yang menjelaskan tentang pentingnya peranan komunitas dalam pembangunan pariwisata atau biasa disebut dengan Community Based Tourism (CBT). Secara konsep, prinsip dasar pembangunan pariwisata berbasis masyarakat merupakan dengan menempatkan masyarakat sebagai komponen utama yang dapat dilakukan untuk pemberdayaan masyarakat dalam berbagai macam kegiatan kepariwisataan, sehingga manfaat dari kepariwisataan seluruhnya dapat diperuntukkan bagi masyarakat, dimana masyarakat atau penduduk setempat memiliki peranan penting dan utama dalam pengambilan keputusan mempengaruhi dan memberi manfaat terhadap kehidupan dan lingkungan mereka (Prasiasa Oka Putu Dewa, 2012).

Konsep ini bertujuan untuk membuat masyarakat di Desa Wisata Mentawir menjadi sadar dan peka akan potensi wisata yang ada di Desanya. Desa Wisata Mentawir telah membentuk Kelompok Sadar Wisata (Pokdarwis) yang dinamakan Pokdarwis "Tiram Tambun”. Fungsi Kelompok Sadar Wisata Menurut buku panduan Kelompok Sadar Wisata (Rahim , 2012) adalah sebagai penggerak Sadar Wisata dan Sapta Pesona di lingkungan objek pariwisata. Sebagai Mitra Pemerintah dan pemerintah daerah (kabupaten/kota) dalam upaya perwujudan dan pengembangan sadar wisata di daerah tersebut. Fungsi dari Kelompok Sadar Wisata yaitu sebagai penggerak sadar wisata dan Sapta Pesona, sebagai mitra pemerintah dalam mewujudkan dan pengembangan wisata di daerah tersebut.

\section{METODE PELAKSANAAN}

Dalam pengabdian kepada masyarakat ini metode pelaksanaan yang dilakukan yaitu dengan melakukan kegiatan-kegiatan sebagai berikut. 
a. Sosialisasi

Sosialisasi menurut kamus besar Bahasa Indonesia berarti upaya memasyarkatkan sesuatu sehingga menjadi dikenal, dipahami, dihayati oleh masyarakat atau pemasyarakatan.

Kegiatan sosialisasi merupakan kegiatan awal dimana mitra akan diberikan informasi secara jelas mengenai kegiatan yang akan dilakukan termasuk persiapan pelatihan sehingga diharapkan partisipasi dari mitra bisa maksimal

b. Pelatihan

Kegiatan pelatihan dilakukan untuk meningkatkan pengetahuan dan keterampilan agar dapat menyelesaikan kendala atau permasalahan yang dihadapi dalam melaksanakan suatu kegiatan atau pekerjaan.

c. Pendampingan

Pendampingan merupakan strategi yang sangat menentukan keberhasilan program pemberdayaan masyarakat, sesuai dengan prinsip yakni membantu orang (Direktorat Bantuan Sosial, 2007). Pendampingan bisa juga dikatakan sebagai kegiatan mentoring yakni sebagai sebuah aktivitas bimbingan dari seseorang yang sudah sangat menguasai hal-hal tertentu dan membagikan ilmunya kepada orang yang membutuhkannya (Salim, 2014). Kegiatan pendampingan dilakukan secara sistematis dan berkelanjutan setelah pelaksanaan kegiatan pelatihan dengan melakukan memberikan pengarahan dan penilaian (coaching) terhadap hasil penerapan dari pelatihan yang sudah diterima di lapangan. Untuk itu pendampingan yang terdiri dari dosen dan mahasiswa yang melakukan kegiatannya melalui Program Pengabdian kepada Masyarakat ( PkM) tidak bisa berperan secara terus menerus tinggal di desa seperti tenaga pendamping desa profesional dan pendamping desa formal sebagaimana ditugasi oleh pemerintah. PkM bersifat sementara walaupun bisa berlanjut oleh perguruan tinggi lain atau perguruan tinggi yang sama oleh angkatan lain (Deputi Bidang Pengembangan Industri \& Kelembagaan. 2019).

d. Monitoring dan evaluasi (monev) yang dilakukan bersamaan dengan kegiatan pendampingan yang dimana waktu pelaksanaannya disesuaikan dengan kebutuhan baik secara langsung maupun tidak langsung dengan menggunakan media komunikasi telepon atau whatsapp (WA) untuk melihat perkembangan dan ketercapaian dari kegiatan secara keseluruhan

\section{HASIL DAN PEMBAHASAN}

Rangkaian kegiatan pengabdian kepada masyarakat dilakukan selama 5 (lima) bulan dengan hasil-hasil yang dicapai yakni :

a. Kegiatan sosialisasi ( Gambar 5) dilakukan dengan Pengurus Pokdarwis Tiram

Tambun dengan tujuan sebagai berikut.

1) Memberikan informasi dan gambaran tentang tujuan dan rangkaian program kegiatan pengabdian masyarakat secara keseluruhan.

2) Memberikan motivasi agar dapat mengikuti pelaksanaan kegiatan dengan kesungguhan dan tanggungjawab. 
3) Melakukan kesepakatan mengenai rencana waktu pelaksanaan kegiatan terutama untuk penyuluhan, pelatihan dan pendampingan
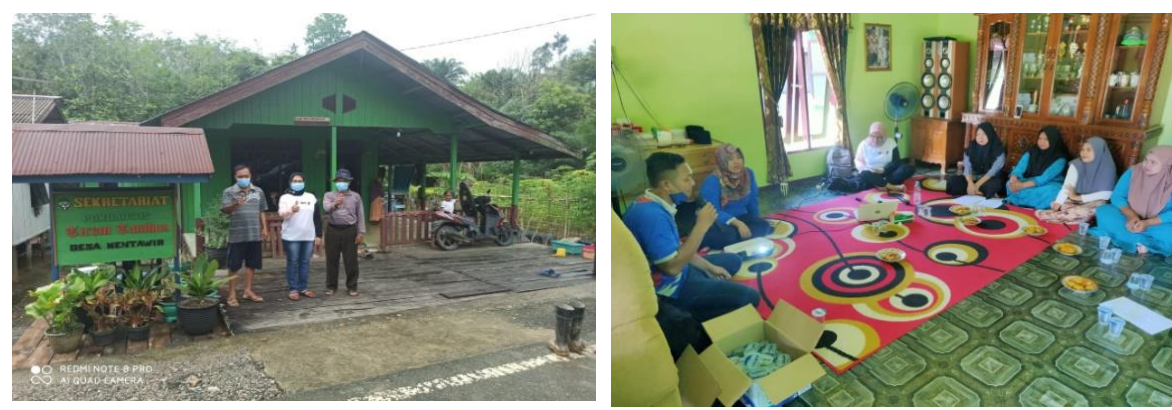

Gambar 5. Pelaksanaan Kegiatan Sosialisasi

Sumber : Tim Pelaksana PkM Poltekba

b. Pelatihan

Kegiatan ini dilakukan pada hari Minggu tanggal 26 September 2020 bertempat di Hotel Tjokro Balikpapan dengan menerapkan protokol kesehatan yang sangat ketat dimana semua personil yang terlibat dalam kegiatan ini harus melaui pemeriksaan Rapid Test. Peserta yang mengikuti kegiatan ini sebanyak 20 orang dari perwakilan anggota Pokdarwis Tiram Tambun yang langsung didampingi oleh Lurah Mentawir. Kegiatan ini juga dihadiri oleh Kepala Bidang Pariwisata Dan Pemasaran Dinas Kebudayaan dan Pariwisata Kabupaten Panajam Paser Utara serta perwakilan dari Kemenparekkraf. Dalam pelatihan (Gambar 6) ini diberikan materi yang diberikan yakni: a) Homestay; b) Standar Kriteria Homestay; c) Pelayanan Penataan Kamar Homestay; d) Cleanness, Healthy, Safety \& Environment (CHSE). Respon dan partisipasi yang ditunjukkan peserta pada pelatihan ini sangat baik. Hal ini ditunjukan dengan banyaknya pertanyaan dari peserta unutk materi-materi yang diberikan oleh para narasumber dari tim pengabdian kepada masyarakat.
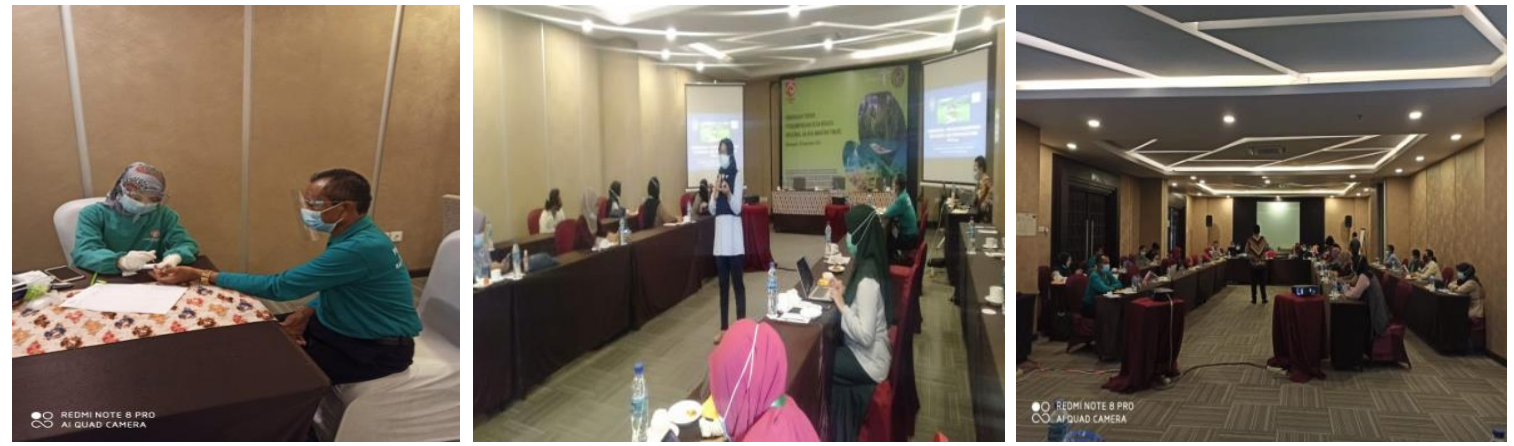

Gambar 6. Pelaksanaan Kegiatan Pelatihan

Sumber : Tim Pelaksana PkM Poltekba 
c. Pedampingan serta monitoring dan evaluasi

Kegiatan pendampingan yang dilakukan oleh tim pengabdian kepada masyarakat dilakukan sekaligus dengan kegiatan monitoring dan evaluasi (Gambar 7). Pendampingan yang juga dilakukan dalam bentuk coaching untuk memberikan pengarahan dan membantu permasalahan mitra terhadap pelaksanaan hasil pelatihan yang telah dilakukan sedangkan monitoring dan evaluasi menilai dan mengevaluasi dari perkembangan dan ketercapaian dari kegiatan. Pendampingan dilakukan sebanyak 3 (tiga) kali untuk melihat dampak dari kegiatan yang dilakukan. Hasil dari pendampingan awal bisa dilihat dari adanya penambahan jumlah homestay yang semula hanya 1 (satu) yakni saja bertambah menjadi 3 (tiga) homestay.
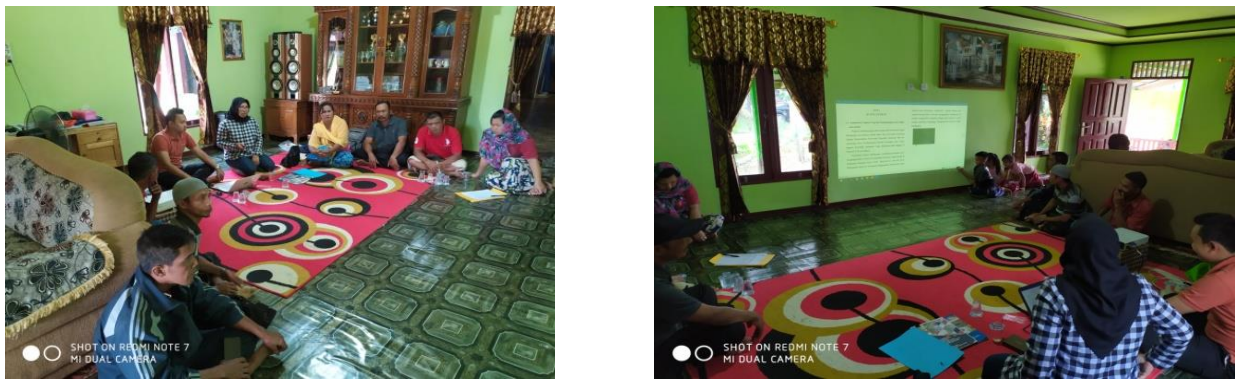

Gambar 7. Pelaksanaan Kegiatan Pendampingan I

Sumber : Tim Pelaksana PkM Poltekba

Hasil pendampingan selanjutnya (Gambar8) perkembangannya bisa dilihat dengan adanya beberapa penambahan dari pemenuhan kriteria standar homestay untuk aspek produk seperti sudah tersedianya tempat sampah di kamar tamu dan kamar mandi, tersedianya meja dan kaca rias di kamar tamu dan beberapa fasilitas lainnya yang dibutuhkan oleh tamu bila menginap di homestay. Namun demikian untuk aspek pelayanan dan pengelolaan masih perlu dilakukan peningkatan. Belum bisa diterapkannya ketrampilan menata kamar tamu dengan baik terutama dalam penataan tempat tidur mengharuskan tim pengabdian kepada masyarakat untuk kembali melatih tentang hal tersebut. Pada kesempatan ini juga diberikan bantuan sumbangan lena kamar dari pihak hotel dan dari pihak tim PkM agar bisa dimanfaatkan oleh para pemilik homestay. Hal lain yang perlu diperbaiki juga administrasi sederhana untuk pencatatan pemesanan, pendaftaran tamu menginap dan pembayaran tamu masih belum dibuat sehingga perlu kembali diberikan arahan bagaimana untuk membuat dan menangani administrasi tersebut. 

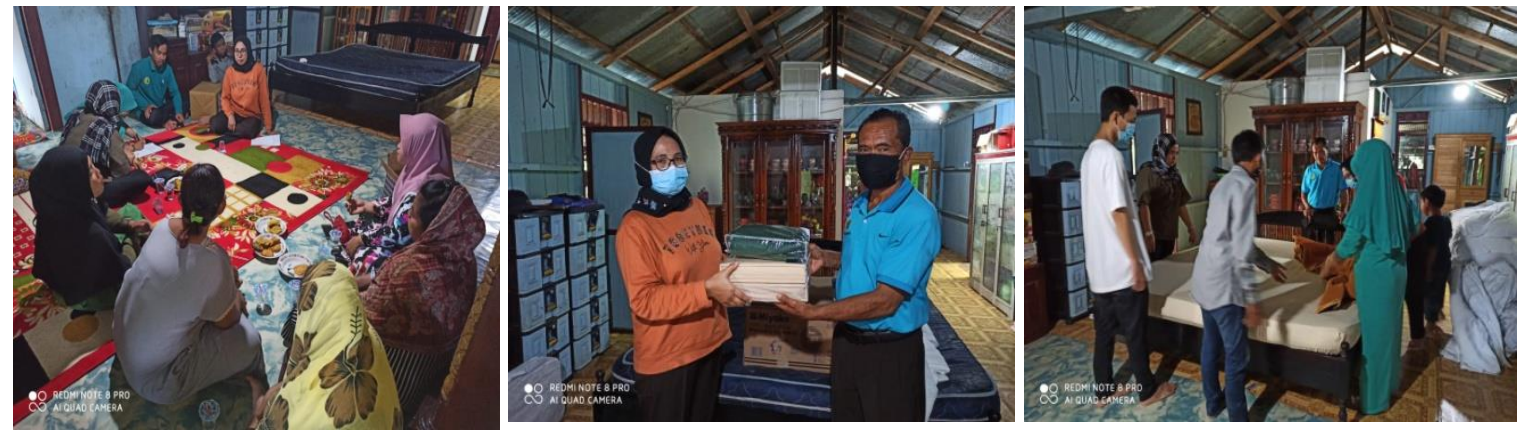

Gambar 8. Pelaksanaan Kegiatan Pendampingan II Sumber : Tim Pelaksana PkM Poltekba

Hasil pendampingan terakhir yang dilakukan sudah didapatkan peningkatkan yang cukup baik dengan sudah bisa diterapkannya ketrampilan untuk penataan tempat tidur juga sudah tersedianya buku-buku untuk pencatatan administrasi homestay sebagaimana terlihat di Gambar 9.
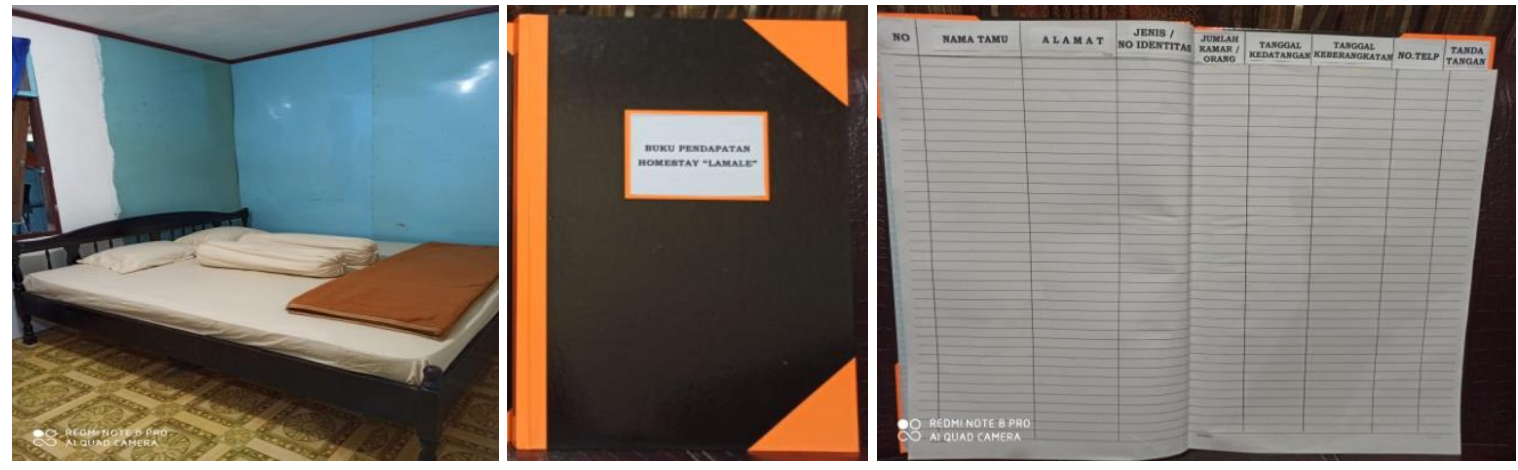

Gambar 9. Penerapan Hasil Pelatihan Pada pendampingan III Sumber : Tim Pelaksana PkM Poltekba

\section{UCAPAN TERIMA KASIH}

Kegiatan Pengabdian Kepada Masyarakat ini dapat dilaksanakan dengan baik dan tanpa ada kendala tentunya tidak terlepas dari dukungan dan bantuan baik dari semua pihak baik secara langsung ataupun tidak langsung. Oleh karena kami mengucapkan terima kasih kepada Pokdarwis Tiram Tambun atas kerjasama dan semangatnya untuk menjadi mitra, Politeknik Negeri Balikpapan yang telah memberikan dana kegiatan, Kementerian Pariwisata dan Ekonomi Kreatif Republik Indonesia yang telah memberikan pembinaan dalam kegiatan pendampingan Desa Wisata serta Dinas Kebudayaan dan Pariwisata Kab.Panajam Paser Utara.

\section{KESIMPULAN}

Dari pelaksanaan kegiatan pengabdian kepada masyarakat untuk pemberdayaan Pokdarwis Tiram Tambun dalam mengembangkan usaha homestay di Desa Wisata Mentawir Kabupatem Panajam Paser Utara dapat disimpulkan bahwa kegiatan pengabdian kepada 
masyarakat ini dapat meningkatkan wawasan serta menambah pengetahuan dan ketrampilan akan pengelolaan homestay yang mana hal ini ditunjukan dengan adanya penambahan jumlah homestay serta adanya usaha untuk memenuhi beberapa standar kriteria homestay.

\section{Ucapan Terimakasih}

Kegiatan ini disuport oleh Kementerian Pariwisata dan Ekonomi Kreatif Republik Indonesia melalui kolaborasi pendanaan dan implementasi program. Ucapak terimaksih juga diucapkan untuk Pusat Penelitian dan Pengabdian kepada Masyarakat Politeknik atas dukungan sarana dan pengesahan kegiatan, termasuk semua tim pelaksana dan mahasiswa yang terlibat.

\section{Daftar Pustaka}

A.J, Mulyadi. (2012). Kepariwisataan dan Perjalanan, Jakarta: Raja Grafindo Persada. ASEAN Homestay Standard. (2011). https://tourism.gov.mm/wpcontent/uploads/2019/05/ Asean-Homestay-Standard.pdf

Deputi Bidang Pengembangan Industri \& Kelembagaan. (2019). Pengembangan Desa Wisata Berbasis Pendampingan Melalui Perguruan Tinggi. Jakarta: Kementerian Pariwisata

Direktorat Bantuan Sosial. (2007). Pedoman Pendamping Pada Rumah Perlindungan dan Trauma Center. Jakarta : Departemen Sosial

Gendro, Salim. (2014). Effective Coaching. Jakarta : PT Buana Ilmu Populer http://kbbi.web.id/sosialisasi

Krisnawati, N., Krisanto, D. (2018). Pemberdayaan Masyarakat Desa Wisata Melalui Homestay Dalam Meningkatkan Ekonomi Pedesaan Di Tanjung Lesung Jjawa Barat. Prosiding PKM-CSR, Vol. 1 (2018). e-ISSN: 2655-3570

Marpaung, H. dan Herman, B. 2000. Pengantar Pariwisata. Bandung: Penerbit Alfabeta.

Permenparekraf No.18 Tahun 2018. Pendaftaran Usaha Pariwisata. https://www.kemenparekraf.go.id/post/peraturan-menteri-pariwisata-nomor-18-tahun2016

Prasiasa Oka Putu Dewa, 2012, Pariwisata Berbasis Masyarakat, Bali: Salemba Humanika

Priasukmana Soetarso dan R. Mohamad Mulyadin, 2013, Pembangunan Desa Wisata: Pelaksanaan Undang-undang Otonomi Daerah, jurnal

Rahim Ir. Firmansyah. (2012). Pedoman Kelompok Sadar Wisata, Jakarta : Kementerian Pariwisata dan Ekonomi Kreatif 
Tim Master Trainer Desa Wisata (2019). Desa Wisata. Jakarta: Deputi Bidang Pengembangan Industri \& Kelembagaan Kementerian Pariwisata

Undang-Undang Republik Indonesia No.10 Tahun 2009. https://www.kemenparekraf.go.id/ post/undang-undang-republik-indonesia-nomor-10-tahun-2009 